\title{
UPAYA MENINGKATKAN HASIL BELAJAR IPA MELALUI PENDEKATAN INQUIRY DENGAN MEMANFAATKAN MEDIA GAMBAR PADA SISWA KELAS III SD NEGERI 19 KEPAHIANG SEMESTER I TAHUN 2016
}

Jalius

SDN 19 Kepahiang

\begin{abstract}
Abstrak
Penelitian ini bertujuan untuk dapat meningkatan hasil belajar siswa pada mata pelajaran IPA yang kurang optimal. Jenis penelitian yang dilakukan adalah penelitian tindakan kelas yang dilaksanakan dalam 2 siklus. Subjek penelitian ini adalah siswa kelas III SD Negeri 19 Kepahiang Semester I Tahun 2016 yang berjumlah 20 siswa. Teknik pengumpulan data menggunakan penilaian tertulis untuk memperoleh data hasil belajar IPA dan observasi untuk melihat kinerja guru dan aktivitas belajar siswa selama proses pembelajaran IPA.. Hasil belajar pada siklus I diperoleh dari tes yang dilaksanakan pada akhir pertemuan siklus I dengan ketuntasan klasikal $60 \%$ atau 12 siswa yang tuntas, meningkat pada siklus II yaitu ketuntasan klasikal belajar siswa mencapai $90 \%$ atau 18 siswa tuntas dari 20 siswa. Dengan demikian dapat disimpulkan bahwa bahwa melalui pendekatan inquiri dengan memanfaatkan media gambar akan mendapatkan teori baru tentang peningkatan hasil belajar IPA siswa kelas III. Siswa merasa tertarik dan mudah memahami materi pelajaran IPA melalui pendekatan inquiri dengan menggunakan media gambar dalam pembelajaran.
\end{abstract}

Kata Kunci: Pendekatan Inquiri, Media Gambar, Hasil Belajar, IPA

\section{PENDAHULUAN}

Mutu pendidikan khususnya di sekolah dasar menjadi fokus perhatian dalam rangka meningkatkan kualitas sumber daya manusia yang diupayakan melalui berbagai usaha pembangunan pendidikan yang lebih berkualitas antara lain melalui pengembangan dan perbaikan kurikulum, pengembangan dan pengadaan materi ajar serta pelatihan bagi guru Upaya tersebut belum cukup berarti dalam meningkatkan kualitas pendidikan dan yang harus diperhatikan saat ini yaitu siswa mengalami kesulitan dalam mata pelajaran IPA.

Berdasarkan latar belakang masalah, dapat ditemukan masalah yang menyebabkan rendahnya hasil belajar IPA pada siswa kelas III SD Negeri 19 Kepahiang. Permasalahan tersebut antara lain : minat siswa dalam belajar IPA masih ada yang kurang, siswa kurang meperhatikan pelajaran. Atas dasar pengalaman mengajar sehari-hari menunjukkan kondisi yang belum mengalami perubahan yang signifikan dan siswa cenderung ada yang lupa pada pelajaran yang sudah diberikan. Sehingga menyebabkan ketuntasan belajar klasikal siswa kelas III SD Negeri 19 Kepahiang pada pelajaran IPA hanya $60 \%$ siswa dengan nilai rata-rata hanya 4,9.

penelitian ini dilakukan untuk meningkatkan hasil belajar IPA melalui pendekatan iquiri dengan memanfaatkan media gambar pada siswa kelas III SD Negeri 19 Kepahiang. Mafaat bagi Siswa Siswa akan mudah memahami materi pelajaran IPA melalui pendekatan inquiri dengan meggunakan media gambar dalam pembelajaran. Bagi Guru dapat menemukan pengalaman dalam pembelajaran pendekatan inquiri menggunakan media gambar sebagai objek yang diamati untuk meningkatkan hasil belajar IPA pada siswa kelas III. Bagi Sekolah Dapat digunakan untuk memotivasi guru, agar dapat memanfaatkan media pembelajaran yang ada di sekolah yang dapat meningkatkan kualitas pembelajaran dengan pendekatan inquiri. 
Pembelajaran merupakan kegiatan yang dilakukan untuk menginisiasi, memfasilitasi dan meningkatkan intensitas dan kualitas belajar pada diri peserta didik. Pembelajaran tidak dapat dipisahkan dari proses dan hasil belajar. Pembelajaran harus dengan sengaja diorganisasikan dengan baik agar dapat menumbuhkan proses belajar yang baik yang ada gilirannya dapat mencapai hasil belajar yang optimal. Udin S. Winataputra, (2008:19) menyimpulkan "pembelajaran adalah proses interaksi antara peserta didik dengan pendidik dan sumber belajar pada suatu lingkungan belajar".

Sugandi, (2004:10) mendifinisikan prinsip pembelajaran yang bersumber dari teori behavioristik yaitu pembelajaran dapat menimbulkan proses belajar dengan baik bila (1) di belajar berpartisipasi secara aktif, (2) materi disusun dalam bentuk unit-unit kecil dan diorganisir secara sistematis dan logis, dan (3) tiap respon si pebelajar diberi balikan dan disertai penguatan.

\section{METODE}

Jenis penelitian ini adalah penelitian tindakan kelas. Penelitian tindakan kelas ini merupakan penelitian yang dilakukan oleh Guru di dalam kelasnya sendiri melalui refleksi diri dengan tujuan untuk memperbaiki kinerjanya sebagai Guru sehingga kualitas proses dan hasil belajar siswa meningkat (Wardhani, 2007). Subjek dalam penelitian ini adalah siswa kelas III SD Negeri 19 Kepahiang Semester I Tahun 2016 yang berjumlah 20 siswa. Teknik pengumpulan data menggunakan penilaian tertulis untuk memperoleh data hasil belajar IPA dan observasi untuk melihat kinerja guru dan aktivitas belajar siswa selama proses pembelajaran IPA. Prosedur penelitian ini terdiri dari empat tahap yaitu: (1) perencanaan (Planing), (2) pelaksanaan tindakan (action), (3) pengamatan (observation), dan (4) refleksi (reflektion) (Arikunto, 2006). Data hasil penelitian ini dianalisis secara deskriptif dengan ketentuan skor untuk setiap aspek yang diamati.
Dari hasil penelitian yang telah dilakukan aktivitas belajar siswa selama mengikuti pembelajaran inquiri dengan memanfaatkan media gambar diperoleh hasil observasi sebagai berikut:

\section{Siklus I}

Penilaian aktivitas belajar siswa pada pertemuan pertama memperoleh skor 27 dengan presentase $48 \%$. Bisa dikatakan pertemuan pertama aktivitas belajar siswa kurang karena siswa belum terbiasa dengan pembelajaran inquiri yang dilakukan. Pada pertemuan kedua siklus I meningkat menjadi 68\% dengan kategori cukup baik. Ini menandakan kegiatan pembelajaran siklus I kurang berhasil.

\section{Refleksi siklus I}

Nilai tertinggi yang diperoleh siswa pada siklus I belum ada yang mencapai nilai maksimum yaitu 100, nilai tertinggi yang didapat beberapa siswa hanya 80 dan nilai terendah 40 . Perolehan hasil belajar IPA siswa kelas III SD Negeri 19 Kepahiang melalui pembelajaran inquiri dengan memanfaatkan media gambar jumlah siswa yang nilainya memenuhi KKM belum meningkat.

Data diatas menunjukkan siswa yang tuntas pada siklus I mencapai $60 \%$ atau 12 siswa, sedangkan siswa yang belum tuntas hasil belajarnya $40 \%$ atau 8 siswa meningkat dibandingkan hasil belajar pra siklus. Namun demikian hasil yang diperoleh pada siklus I belum mencapai standar yang telah ditetapkan pada indikator kinerja pada penelitian ini. Indikator keberhasilan penelitian ini dianggap berhasil apabila siswa yang tuntas hasil belajarnya berjumlah 12 siswa atau ketuntasan klasikal 60\%. Dari data yang diperoleh pembelajaran inquiri dengan memanfaatkan media gambar pada siklus I belum berhasil karena ketuntasan belajar siswa baru mencapai $60 \%$ atau 12 siswa, sehingga penelitian dilanjutkan pada siklus II.

\section{Siklus II}

Penilaian aktivitas belajar siswa pada pertemuan pertama memperoleh skor 48 dengan nilai presentase $86 \%$ dikategorikan baik sekali. Pada pertemuan kedua siklus II meningkat, skor

\section{HASIL}


menjadi 52 nilai presentasenya $93 \%$ dikategorikan baik sekali.

\section{Refleksi siklus II}

Jumlah siswa yang tuntas belajarnya pada siklus 2 secara langsung mengalami peningkatan menjadi 17 siswa. Nilai tertinggi yang diperoleh siswa pada siklus I sudah ada yang mencapai nilai maksimum yaitu 96 dan nilai terendah 50. Perolehan hasil belajar IPA siswa kelas III SD Negeri 19 Kepahiang pada siklus II melalui pembelajaran inquiri dengan memanfaatkan media gambar jumlah siswa yang nilainya memenuhi KKM meningkat. Data menunjukkan siswa yang tuntas pada siklus II mencapai $85 \%$ atau 17 siswa, sedangkan siswa yang belum tuntas hasil belajarnya hanya $15 \%$ atau 3 siswa dibandingkan hasil belajar pada siklus I. Jadi dikatakan siklus II berhasil, karena sudah memenuhi indikator kinerja dalam penelitian ini yaitu 17 siswa tuntas dalam kelas.

\section{DISKUSI}

hasil tersebut bahwa kegiatan guru mengajar dengan pembelajaran inquiri memanfaatkan media gambar pada siklus I pertemuan pertama yaitu $48 \%$ dengan kategori kurang dan pertemuan kedua $70 \%$ dengan kategori cukup baik. Sedangkan pada siklus II mengalami peningkatan pada pertemuan pertama menjadi $86 \%$ dengan kategori baik sekali dan pada pertemuan kedua 96\% dengan kategori baik sekali. Dapat disimpulkan kegiatan pembelajaran inquiri dengan memanfaatkan media gambar dari setiap pertemuan mengalami peningkatan yang ditunjukkan dari nilai presentase kegiatan guru mengajar. Pembelajaran inquiri dengan memanfaatkan media gambar mengajar, maka dapat dikatakan kegiatan pembelajaran siklus II berhasil. Ketuntasan klasikal hasil belajar IPA siswa kelas III SD Negeri 19 Kepahiang telah dilakukan tindakan dengan pembelajaran inquiri dengan memanfaatkan media gambar pada siklus I ketuntasan belajar IPA siswa $60 \%$. Sedangkan pada siklus 2 adalah $85 \%$. Jumlah tuntas hasil belajar IPA pada siklus I ada 12 siswa sedangkan siklus II meningkat lagi menjadi 17 siswa. Nilai rata-rata IPA mengalami peningkatan dari siklus I yaitu 60 meningkat setelah diberikan tindakan pada siklus II nilai rata-rata meningkat menjadi 73.

\section{SIMPULAN}

Dari hasil penelitian ini dapat ditarik kesimpulan bahwa melalui pembelajaran inquiri dengan memanfaatkan media gambar yang dilakukan pada siswa kelas III SD Negeri 19 Kepahiang semester 1 tahun 2016 dapat meningkatkan hasil belajar siswa pada pelajaran IPA.

\section{SARAN}

bahwa melalui pendekatan inquiri dengan memanfaatkan media gambar akan mendapatkan teori baru tentang peningkatan hasil belajar IPA siswa kelas III. Sebagai dasar untuk penelitia selanjutnya. Siswa merasa tertarik dan mudah memahami materi pelajaran IPA melalui pendekatan inquiri dengan menggunakan media gambar dalam pembelajaran.

\section{DAFTAR PUSTAKA}

Udin. S. Winatraputra dkk.2008. Teori Belajar dan Pembelajaran. Jakarta: Universitas Terbuka

Sugandi. 2004. Teori Pembelajaran, Jakarta: Rajawali Pers. 